\title{
Ekstrak Etanol Propolis Menurunkan Kadar IL-17 Serum pada Mencit Balb/C Model Asma Kronik
}

\author{
Sri Hartati H., ${ }^{1}$ Sarsono, ${ }^{1}$ Siti Aisyah, ${ }^{1}$ Diding H. P. ${ }^{1,2}$ \\ ${ }^{1}$ Laboratorium Biokimia Fakultas Kedokteran Universitas Sebelas Maret Surakarta \\ ${ }^{2}$ Divisi Imunologi-Laboratorium Biokimia Fakultas Kedokteran Universitas Sebelas Maret Surakarta
}

\begin{abstract}
Abstrak
Interleukin-17 (IL-17) menginduksi perekrutan neutrofil ke dalam saluran napas dan berperan dalam patogenesis asma serta penentuan keparahan penyakit. Tujuan penelitian ini adalah menganalisis efek ekstrak etanol propolis (EEP) isolat Gunung Lawu terhadap kadar IL-17 serum pada mencit Balb/C model asma kronik. Penelitian ini merupakan penelitian eksperimental laboratoris dengan sampel 28 ekor mencit Balb/C jantan yang dibagi menjadi empat kelompok: kontrol, asma, asma+EEP, dan asma+antihistamin. Penelitian dilakukan di Laboratorium Histologi dan Biomedik, Fakultas Kedokteran, Universitas Sebelas Maret, Surakarta, selama periode AprilSeptember 2012. Model asma kronik dibuat dengan menginduksi mencit Balb/C jantan menggunakan injeksi intraperitoneal (i.p.) ovalbumin (OVA, $100 \mu \mathrm{g} / \mathrm{mencit})$ dan aluminium hidroksida $(10 \%, 50 \mathrm{mg} / \mathrm{mencit})$ dalam phosphate-buffered saline (PBS). Hewan coba disensitisasi selama 6 minggu dengan inhalasi 2\% (b/v) OVA aerosol dalam $\mathrm{NaCl}$ 0,9\% selama 30 menit/hari setiap 3 hari/minggu, untuk kelompok asma, asma+EEP, dan asma+antihistamin. Mencit kontrol tidak diinokulasi selama penelitian. Deteksi kadar IL-17 serum menggunakan enzyme-linked immunosorbent assay (ELISA). Uji kadar IL-17 serum menggunakan analysis of variance (ANOVA) dan untuk menentukan perbedaan kemaknaan digunakan $\mathrm{p}<0,05$. Kadar IL-17 serum kelompok kontrol menunjukkan $17,15 \pm 8,25 \mathrm{pg} / \mathrm{mL}$ dan antihistamin $38,98 \pm 7,57 \mathrm{pg} / \mathrm{mL}$. Ekstrak etanol propolis secara bermakna menurunkan kadar IL-17 serum $(75,62 \pm 17,64 \mathrm{pg} / \mathrm{mL}$ vs $45,59 \pm 10,69 \mathrm{pg} / \mathrm{mL}, \mathrm{p}<0,001)$ dibandingkan dengan kelompok asma. Simpulan, EEP isolat Gunung Lawu menurunkan kadar IL-17 pada hewan coba model asma kronik. [MKB. 2013;45(4):213-7]
\end{abstract}

Kata kunci: Asma, interleukin-17 (IL-17), propolis

\section{Ethanolic Extract of Propolis Decreases Serum IL-17 Levels in Balb/C Model of Chronic Asthma}

\begin{abstract}
Interleukin-17 (IL-17) induces the neutrophil recruitment into the respiratory tract while playing a role in the pathogenesis of asthma and determining the severity of disease. The aim of this study was to analyze the effect of ethanol extract of propolis (EEP) Lawu mountain isolates on IL-17 serum levels in Balb/C mice model with chronic asthma. This study was an experimental research laboratory with 28 male Balb/C mice divided into control, asthma, asthma+EEP and asthma+antihistamine groups. The study was conducted at the Histology and Biomedical Laboratory, Faculty of Medicine, Sebelas Maret University, Surakarta, during April to September 2012. A model of chronic asthma was induced in male Balb/C mice using an intraperitoneally (i.p.) injection ovalbumin (OVA, $100 \mu \mathrm{g} / \mathrm{mice})$ and aluminum hydroxide $(10 \%, 50 \mathrm{mg} / \mathrm{mice})$ in phosphate-buffered saline (PBS). Experimental animals were sensitized for 6 weeks with inhaled $2 \%(\mathrm{w} / \mathrm{v})$ OVA aerosol in $0.9 \% \mathrm{NaCl}$ for 30 minutes/day, 3 days in a week, for asthma, asthma with EEP, and asthma with antihistamine mice model groups. Control mice were not inoculated during the study. Detection of IL-17 serum level was conducted by using enzyme-linked immunosorbent assay (ELISA). One way analysis of variance (ANOVA) for IL-17 serum level and $\mathrm{p}<0.05$ were used to determine significant differences. Serum levels of IL-17 showed $17.15 \pm 8.25 \mathrm{pg} / \mathrm{mL}$ in control group and $38.98 \pm 7.57 \mathrm{pg} / \mathrm{mL}$ in antihistamine, respectively. Ethanol extract of propolis showed significant decreased in IL17 levels $(75.62 \pm 17.64 \mathrm{pg} / \mathrm{mL}$ vs $45.59 \pm 10.69 \mathrm{pg} / \mathrm{mL}, \mathrm{p}<0.001)$ compared to asthma group. In conclusion, EEP Lawu mountain isolates can decrease IL-17 level in chronic asthma animal models. [MKB. 2013;45(4):213-7]
\end{abstract}

Key words:Asthma, interleukin-17 (IL-17), propolis

Korespondensi: Sri Hartati Hadinoto, dra., Apt., SU, Lab. Biokimia Fakultas Kedokteran Universitas Sebelas Maret Surakarta. Jl IR Sutami 36A Kentingan Jebres Surakarta, mobile 08122651651, email diding_hape@yahoo.co.id 


\section{Pendahuluan}

Asma merupakan suatu penyakit inflamasi yang bersifat kronik saluran pernapasan sebagai hasil interaksi faktor imunitas selular maupun humoral. Interaksi antarkedua faktor imunitas tersebut pada asma alergi akan tercermin dalam bentuk airway hyperresponsiveness (AHR), bronkokonstriksi, sekresi mukus, dan juga remodeling. Komponen selular yang utama pada terjadinya reaksi alergi inflamasi yaitu sel mast, basofil, eosinofil, dan sel-sel $T$ helper 2 (Th2), sedangkan komponen humoral utamanya yaitu imunoglobulin $\mathrm{E}(\mathrm{IgE}){ }^{1}$ Hasil interaksi sel dan mediator pada akhirnya akan meninggikan kadar reactive oxygen species (ROS) dan reactive nitrogen species (RNS). Banyak penelitian mengidentifikasi bahwa ROS, RNS, dan kehilangan pertahanan antioksidan berpartisipasi dalam patogenesis asma. ${ }^{2}$

Meskipun ciri khas pada asma diperantarai eosinofil, sel mast, dan sel Th2, pada asma yang parah terjadi peningkatan neutrofil. Interleukin-17 (IL-17) akan menginduksi perekrutan neutrofil ke dalam saluran napas, sehingga sitokin ini penting dalam proses patogenesis asma dan menentukan keparahan penyakit. Persentase sel Th17 serta kadar IL-17 pada saluran pernapasan dan plasma cenderung meningkat dengan parahnya penyakit penderita asma. ${ }^{3}$

Berbagai obat baru ditemukan dan digunakan untuk dapat mengatasi penyakit asma. Pengobatan secara tuntas yang dapat diberikan pada semua individu tampaknya belum ada sampai saat ini. Salah satu obat alam yang telah digunakan untuk mengatasi asma yaitu propolis lebah, akan tetapi mekanismenya belum dipahami dengan jelas.

Senyawa yang terkandung dalam propolis, antara lain caffeic acid phenethyl ester (CAPE) dan kuersetin. Caffeic acid phenethyl ester merupakan antioksidan fenolik yang menunjukkan aktivitas antiinflamasi dan penghambat aktivasi nuclear factor-kappa B (NF-кB). Kuersetin dapat mengurangi aktivasi NF- $\kappa B$, yaitu suatu kompleks faktor transkripsi yang sangat berperan dalam ekspresi gen proinflamasi. Selain itu, kuersetin juga memiliki efek menghambat aktivasi sel mast dan pelepasan histamin, tumor necrosis factoralpha (TNF- $\alpha$ ), IL-6, dan IL-8. ${ }^{4-7}$

Latar belakang penelitian ini karena belum terdapatnya bukti ilmiah penggunaan propolis lebah untuk asma bronkial. Inflamasi sebagai hasil aktivasi NFk-B akan melepaskan mediator sekunder (seperti faktor lipid dan ROS) yang selanjutnya akan memperkuat inflamasi. Keadaan ini akan dapat mengganggu keseimbangan antara oksidan dan antioksidan. Diharapkan pemberian propolis lebah yang memiliki aktivitas biologis berupa imunomodulator, antioksidan, dan juga antiinflamasi mempunyai potensi untuk dapat dikembangkan pada penatalaksanaan asma alergi.

Tujuan penelitian ini adalah menganalisis efek ekstrak etanol propolis (EEP) isolat Gunung Lawu terhadap kadar IL-17 serum pada mencit $\mathrm{Balb} / \mathrm{C}$ model asma kronik.

\section{Metode}

Penelitian ini merupakan penelitian eksperimental laboratoris, dengan sampel diambil dari 28 ekor mencit Balb/C jantan, dengan bobot $\pm 15-20 \mathrm{~g}$ dan berumur 4-6 minggu yang diperoleh dari Unit Pengembangan Hewan Percobaan Universitas Setya Budi, Surakarta. Untuk bahan makanan mencit digunakan pakan mencit standar.

Penentuan besar sampel untuk analisis bivariat menggunakan rumus: ${ }^{8}$

$\mathrm{n}=\left[\frac{\left(Z^{1 / 2} \alpha+Z \beta\right) \sigma}{\delta}\right]^{2}$

\section{Keterangan:}

$\mathrm{n} \quad=$ besar sampel masing-masing kelompok

$\mathrm{Z}^{1 / 2} \alpha=$ nilai standar normal, yang besarnya bergantung pada $\alpha$

$\mathrm{Z} \beta=$ nilainya bergantung pada $\beta$ yang ditentukan (berdasarkan tabel)

$\delta=$ selisih antara variabel terapi rata-rata dan kontrol yang diharapkan oleh peneliti

$\sigma \quad=$ standar deviasi

Dengan rumus tersebut diperoleh minimal sampel tiap kelompok sebanyak tujuh ekor mencit.

Penelitian ini dilaksanakan di Laboratorium Histologi dan Biomedik, Fakultas Kedokteran, Universitas Sebelas Maret, Surakarta, periode April sampai September 2012. Setelah dilakukan adaptasi selama seminggu, hewan coba dibagi menjadi empat kelompok, yaitu kelompok kontrol, asma, asma+propolis (dosis $6 \mathrm{mg} / \mathrm{kgbobot} / \mathrm{hari} /$ oral), dan asma+antihistamin (fexofenadine dosis $0,2 \mathrm{mg} / \mathrm{mencit} /$ hari/oral).

Model mencit asma kronik dibuat dengan cara menyensitisasi mencit pada hari ke-0 dan ke-5 dengan ovalbumin (OVA) $100 \mu \mathrm{g} /$ mencit yang dilarutkan dalam aluminium hidroksida $(10 \%$, $50 \mathrm{mg} / \mathrm{mencit}$ ) dalam phosphate-buffered saline (PBS) secara intraperitoneal. Mulai hari ke-17 sampai ke-44 hewan coba disensitisasi dengan inhalasi $2 \%(\mathrm{~b} / \mathrm{v})$ OVA aerosol dalam $\mathrm{NaCl} 0,9 \%$ selama 30 menit/hari setiap 3 hari/minggu ( 18 kali OVA aerosol), sesuai rekomendasi Komite Etik Fakultas Kedokteran Universitas Sebelas Maret 


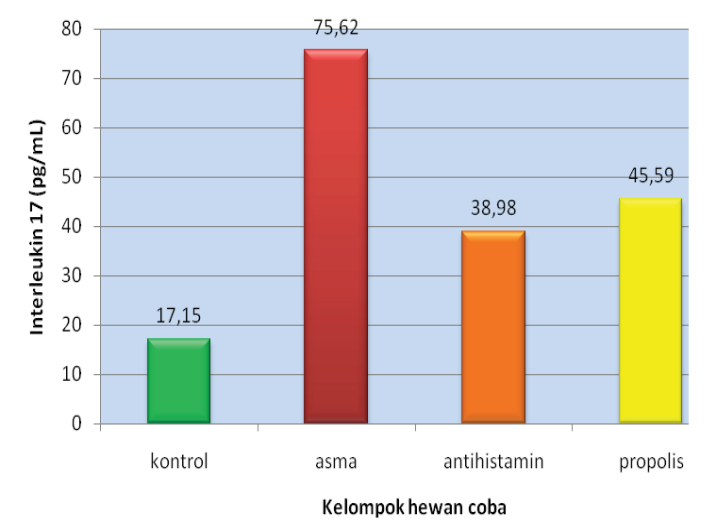

\section{Gambar Kadar IL-17 Rata-rata Tiap Kelompok}

Surakarta. Pada hari ke-44, mencit dikorbankan. ${ }^{9}$ Darah dari jantung mencit diambil sebanyak $1 \mathrm{~mL}$ diencerkan dengan ethylenediaminetetraacetic acid (EDTA) (EDTA:darah=1,5:1), kemudian dilakukan sentrifugasi dengan kecepatan 3.000 rpm, suhu $37^{\circ} \mathrm{C}$ selama 15 menit. Serum hasil koleksi dipergunakan untuk pengukuran kadar IL17 menggunakan enzyme-linked immunosorbent assay (ELISA) kit (IL-17) yang sesuai dengan protokol yang sudah dianjurkan dari pabriknya (Pharmingen, San Diego, California, Amerika Serikat).

Propolis lebah pada penelitian ini diperoleh dari peternak lebah di daerah Kecamatan Kerjo, Kabupaten Karanganyar, Surakarta, Jawa Tengah. Ekstraksi dilakukan dengan metode perkolasi, dengan cairan penyari etanol $80 \%$. Sekitar $1 \mathrm{~g}$ (akurasi penimbangan sampai $0,0001 \mathrm{~g}$ ) bubuk propolis mentah diekstraksi dengan $10 \mathrm{~mL}$ etanol $80 \%$ di-shaker dengan kecepatan $200 \mathrm{rpm}$ pada suhu kamar selama 24 jam. Setelah penyaringan melalui kertas saring, filtrat dibuat hingga $25 \mathrm{~mL}$ dengan $80 \%$ etanol dan disimpan dalam botol sampai analisis. ${ }^{10}$

Data yang diperoleh dianalisis menggunakan program statistical product and service solutions (SPSS) for windows release 15 dan $\mathrm{p}<0,05$ dipilih sebagai tingkat minimal signifikansinya. Uji analysis of variance (ANOVA) atau alternatifnya digunakan untuk analisis data.

\section{Hasil}

Hasil penelitian ini memperlihatkan kadar IL17 serum dalam keadaan normal 17,15 $\pm 8,25 \mathrm{pg} /$ $\mathrm{mL}$ dan setelah pemaparan OVA ternyata secara bermakna $(p<0,001)$ meningkatkan kadar IL-17 serum $(75,62 \pm 17,64 \mathrm{pg} / \mathrm{mL})$. Pemberian ekstrak
Tabel Kadar IL-17 Masing-masing Kelompok

\begin{tabular}{lll}
\hline \multicolumn{1}{c}{ Kelompok } & $\mathbf{n}(\mathbf{p g} / \mathbf{m L})$ & $\begin{array}{c}\text { Mean } \pm \text { Std. } \\
\text { Deviation }\end{array}$ \\
\hline Kontrol & 7 & $17,15 \pm 8,25$ \\
Asma & 7 & $75,62 \pm 17,64$ \\
Antihistamin & 7 & $38,98 \pm 7,57$ \\
Propolis & 7 & $45,59 \pm 10,69$ \\
\hline
\end{tabular}

etanol propolis (EEP) menurunkan kadar IL-17 $(45,59 \pm 10,69 \mathrm{pg} / \mathrm{mL}$ versus $75,62 \pm 17,64 \mathrm{pg} / \mathrm{mL}$, $\mathrm{p}<0,001)$ bila dibandingkan dengan kelompok asma, dan penurunan kadar IL-17 serum dengan EEP sebanding dengan kelompok antihistamin $(45,59 \pm 10,69 \mathrm{pg} / \mathrm{mL}$ versus $38,98 \pm 7,57 \mathrm{pg} / \mathrm{mL}$, $\mathrm{p}=0,303)$.

\section{Pembahasan}

Pemaparan OVA untuk dapat menginduksi mencit model asma alergi pada penelitian ini ternyata meningkatkan kadar IL-17 serum. Keadaan ini karena alergen (OVA) akan terikat pada antigen presenting cells (APC), selanjutnya diproses dan dipresentasikan pada sel Th. Asma alergi dicirikan oleh pengaruh besar sel limfosit Th2 melebihi Th1. Sel Th2 berperan penting dalam inflamasi alergi dengan melepaskan IL-4, IL-5, IL-9, dan IL-13. Interleukin-4 meningkatkan diferensiasi dan proliferasi sel Th2, ${ }^{11}$ serta IL-9 merangsang proliferasi sel mast. ${ }^{1}$ Hasil ini sejalan dengan penelitian Jung dkk., ${ }^{4}$ sensitisasi dan pemaparan OVA pada mencit meningkatkan jumlah eosinofil di dalam cairan bronchoalveolar lavage (BAL), penyempitan saluran napas, AHR, peningkatan TNF- $\alpha$, IL-4 dan IL-5 dalam cairan BAL, dan IgE serum. Peningkatan sitokin Th2 dan kadar IgE serta akumulasi/aktivasi sel Th2, eosinofil dan sel mast pada asma, akan memicu tingginya sekresi IL-17 serum. Interleukin-17 dilaporkan meningkat di paru-paru, dahak, bronchoalveolar lavage fluid (BALF) atau serum penderita asma, dan kadar IL-17 berkorelasi dengan derajat keparahan hipersensitivitas saluran napas pada penderita asma. Hal ini mengisyaratkan bahwa IL-17 berkontribusi pada patogenesis asma. ${ }^{12}$

Pemberian propolis pada penelitian ini secara bermakna menghambat ciri khas reaksi asma kronik, yaitu menurunkan kadar IL-17 serum. Hasil ini sejalan dengan penelitian oleh Okamoto dkk., ${ }^{13}$ bahwa propolis mampu menghambat diferensiasi Th17. Mekanisme EEP menurunkan kadar IL-17 kemungkinan disebabkan karena zat aktif yang terkandung dalam propolis, antara lain 
caffeic acid phenethyl ester (CAPE) dan kuersetin. Hasil penelitian oleh Sarsono dkk., ${ }^{14}$ sebelumnya melaporkan kandungan CAPE propolis wilayah Karanganyar yang digunakan adalah $30,24 \pm 3,53$ x $10^{-6} \mathrm{~g}$ dan kandungan kuersetinnya $4,42 \pm 0,50$ $\mathrm{x} 10^{-6} \mathrm{~g}$.

Reactive oxygen species (ROS) meningkatkan aktivitas NF- $\mathrm{kB}$. Hal ini meningkatkan kejadian inflamasi alergi pada penderita asma. Aktivasi faktor transkripsi NF-kB ini akan menginduksi ekspresi sejumlah gen inflamasi secara tidak normal pada asma. Gen ini meliputi sitokin (misal IL-4, IL-5, dan TNF- $\alpha$ ), kemokin (contohnya RANTES dan eotaksin), dan molekul adhesi (contohnya ICAM-1 dan VCAM-1). ${ }^{15}$ Akibatnya akan terjadi ketidakseimbangan oksidan dengan antioksidan di dalam saluran pernapasan pada penderita asma yang diinduksi oleh NF- $\kappa \mathrm{B}$. Hasil ini didukung oleh penelitian Won-Kyo dkk., ${ }^{16}$ bahwa CAPE secara efektif menekan aktivitas NF-kB dalam saluran napas melalui reduksi stres oksidatif.

Caffeic acid phenethyl ester yang terkandung dalam propolis memiliki aktivitas menghambat degranulasi sel mast, ${ }^{17}$ juga selain itu propolis lebah mempunyai aktivitas biologis yaitu sebagai imunomodulator, antioksidan, dan antiinflamasi. Pada penelitian terlihat penurunan kadar sitokin IL-17. Hasil ini sejalan dengan penelitian Lee dkk. ${ }^{18}$ bahwa cafeic acid menghambat pelepasan mediator kimiawi dalam cairan BAL pada hewan coba yang dipapar OVA secara aerosol.

Simpulan, pemberian ekstrak etanol propolis isolat Gunung Lawu mampu menurunkan kadar IL-17 pada hewan coba model asma kronik. Keadaan ini mengindikasikan pemberian propolis dapat sebagai terapi adjuvan untuk menghambat perkembangan penyakit asma alergi yang kronik.

\section{Ucapan Terima Kasih}

Kepada Direktorat Jenderal Pendidikan Tinggi, dari Departemen Pendidikan Nasional Republik Indonesia yang telah mendanai penelitian dalam program DIPA-BLU Universitas Sebelas Maret Nomor 4299/UN27.06/PN/2012.

\section{Daftar Pustaka}

1. Barnes PJ. Pathophysiology of allergic inflammation. Immunol Rev. 2011; 242(1):31-50.

2. Comhair SAA, Erzurum SC. Redox control of asthma: molecular mechanisms and therapeutic opportunities. Antioxid Redox Signaling. 2010;12(1):93-124.
3. Zhao Y, Yang J, Gao YD, Guo W. Th17 immunity in patients with allergic asthma. Int Arch Allergy Immunol. 2009;151(4):297307.

4. Jung WK, Lee DY, Choi YH, Yea SS, Choi I, Park SG, dkk. Caffeic acid phenethyl ester attenuates allergic airway inflammation and hyperresponsiveness in murine model of ovalbumin-induced asthma. Life Sci. 2008;82(13-14):797-805.

5. Ang ESM, Pavlos NJ, Chai LY, Qi M, Cheng TS, Steer JH, dkk. Caffeic acid phenethyl ester, an active component of honeybee propolis attenuates osteoclastogenesis and bone resorption via the suppression of RANKL-induced NF- $\kappa B$ and NFAT activity. J Cell Physiol. 2009;221(3):642-9.

6. Vicentini FT, He T, Shao Y, Fonseca MJ, Verri WA Jr, Fisher GJ, dkk. Quercetin inhibits UV irradiation-induced inflammatory cytokine production in primary human keratinocytes by suppressing NF- $\mathrm{BB}$ pathway. J Dermatol Sci. 2011;61(3):162-8.

7. Park HJ, Lee CM, Jung ID, Lee JS, Jeong YI, Chang JH, dkk. Quercetin regulates Th1/ Th2 balance in a murine model of asthma. Int Immunopharmacol. 2009;9(3):261-7.

8. Murti B. Desain dan ukuran sampel untuk penelitian kuantitatif dan kualitatif di bidang kesehatan. Edisi ke-1. Yogyakarta: Gadjah Mada University Press; 2006.

9. Fernandez-Rodriguez S, Ford WR, Broadley KJ, Kidd EJ. Establishing the phenotype in novel acute and chronic murine models of allergic asthma. Int Immunopharmacol. 2008;8(5):756-63.

10. Fu B, Xue J, Li Z, Shi X, Jiang BH, Fang J. Chrysin inhibits expression of hypoxiainducible factor-1A through reducing hypoxia-inducible factor-1A stability and inhibiting its protein synthesis. Mol Cancer Ther. 2007;6(1):220-6.

11. Barnes PJ. The cytokine network in asthma and chronic obstructive pulmonary disease. $\mathrm{J}$ Clin Invest. 2008;118(11):3546-56.

12. Oboki K, Ohno T, Saito H, Nakae S. Th2 and allergy. Allergol Int. 2008;57(2):121-34.

13. Okamoto Y, Tanaka M, Fukui T, Masuzawa T. Brazilian propolis inhibits the differentiation of Th17 cells by inhibition of interleukin6-induced phosphorylation of signal transducer and activator of transcription 3 . Immunopharm Immunol. 2012;34(5):803-9.

14. Sarsono, Syarifah I, Martini, Prasetyo DH. Identifikasi caffeic acid phenethyl ester dalam ekstrak etanol propolis isolat Gunung Lawu. JBAI. 2012;8(2):132-6.

15. Zhou LF, Zhu Y, Cui XF, Xie WP, Hu AH, Yin 
KS. Arsenic trioxide, a potent inhibitor of NFkappaB, abrogates allergen-induced airway hyperresponsiveness and inflammation. Respir Res. 2006;7:146.

16. Won-Kyo J, Da-Young L, Choi YH, Yea SS, Choi I, Sae-Gwang P, dkk. Caffeic acid phenethyl ester attenuates allergic airway inflammation and hyperresponsiveness in murine model of ovalbumin-induced asthma. Life Sci. 2008;82(13-14):797-805.

17. Yokoda E, Tanifuji S, Yoshida N, Sonoda $\mathrm{Y}$, Kasahara T. Inhibitory effect of caffeic acid phenethyl ester on antigen-induced degranulation in mast cell line. Proceedings of the $128^{\text {th }}$ Annual Meeting of the Pharmaceutical Society of Japan, 2008.

18. Lee JY, Lee JG, Sim SS, Wan-Kyunn W, Kim CJ.Anti-asthmatic effects of phenylpropanoid glycosides from Clerodendron trichotomum leaves and Rumex gmelini herbes in conscious guinea-pigs challenged with aerosolized ovalbumin. Phytomedicine. 2011;18(2-3):134-42. 